\title{
Temporal change in species and functional plant traits in the moist grassland on the Sete Cidades National Park, Piauí, Brazil
}

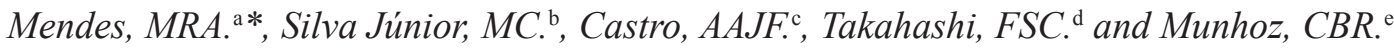 \\ aDepartamento de Biologia, Universidade Estadual do Piauí - UESPI, Av. Nossa Senhora de Fátima, \\ s/n, Nossa Senhora de Fátima, CEP 64202-220, Parnaíba, PI, Brazil \\ ${ }^{b}$ Centro de Referência em Conservação da Natureza e Recuperação de Áreas Degradadas, Universidade de Brasília - UnB, \\ Asa Norte, Campus Darcy Ribeiro, CP 4474, CEP 70910-900, Brasília, DF, Brazil \\ 'Departamento de Biologia, Universidade Federal do Piauí - UFPI, Av. Universitária, 1310, \\ Ininga, CEP 64049-550, Teresina, PI, Brazil \\ ${ }^{\mathrm{d}}$ Departamento de Ecologia, Instituto de Biologia, Universidade de Brasília - UnB, Asa Norte, \\ Campus Darcy Ribeiro, CEP 70910-900, Brasília, DF, Brazil \\ eDepartamento de Botânica, Instituto de Biologia, Universidade de Brasília - UnB, Asa Norte, \\ Campus Darcy Ribeiro, CP 4457, CEP 70910-970, Brasília, DF, Brazil \\ *e-mail: maurarejanem@gmail.com
}

Received: August 30, 2012 - Accepted: January 22, 2013 - Distributed: February 28, 2014

(With 6 figures)

\begin{abstract}
The present study investigated the dynamic on a short-time scale in the vegetation in moist grassland of the Sete Cidades National Park, Piauí. Herb-subshrub layer samples was carried out in July 2007, 2009 and 2011. Changes in structural, floristic and functional traits in the community were assessed by species richness, diversity and similarity indices between those periods, as well as by hierarchical classification and ordination. Cluster and Principal Component Analyses identified functional groups according to 23 species trait state. To distinguish the contribution of space and time configuration in the community structure, we used the variance partition technique. The functional groups of chamaephytes and therophytes II were associated with wetter sites, while the groups of non-tussock hemicriptophytes I, tussock hemicriptophytes (FG4), and geophytes (FG5) were associated to the drier ones. We found a non-accelerated dynamics, at least on a short-time scale, represented by some descriptors in the community, such as the close similarity between the inventories and ordering of sampling transects in moist grassland. Therefore, besides considering the partition of the temporal niche as a mechanism for the co-existence of species, the heterogeneity of space dictated by environmental filters seems to determine the stability of the this grassland communities over time.
\end{abstract}

Keywords: herbaceous and subshrub layer, line intersection method, spatial patterns, temporal patterns, plant functional traits.

\section{Mudança temporal nas espécies e atributos funcionais de plantas em campo limpo úmido de Cerrado no Parque Nacional de Sete Cidades, Piauí, Brasil}

\section{Resumo}

O presente estudo investigou a dinâmica em uma curta escala de tempo na vegetação de campo limpo úmido do Parque Nacional Sete Cidades Park, Piauí. Amostragens da camada herbáceo-subarbustiva foram realizadas em julho de 2007, 2009 e 2011. Mudanças estruturais, florísticas e de atributos funcionais da comunidade foram avaliadas por índices de riqueza de espécies, diversidade e similaridade entre esses períodos, bem como por classificação hierárquica e ordenação. Análise de Componentes Principais e de Cluster identificaram grupos funcionais de acordo com 23 atributos das espécies. Para distinguir a contribuição do espaço e do tempo nas análises, usamos técnicas de partição de variância. Os grupos funcionais das caméfitas e terófitas II foram associados com os locais mais úmidos, enquanto os grupos de hemicriptófitas I não entouceiradas, hemicriptófitos entouceiradas e das geófitas (GF5) foram associados aos mais secos. Nós encontramos uma dinâmica não-acelerada, pelo menos em uma escala de curta duração, representada por alguns descritores da comunidade, tais como a similaridade entre os inventários e a ordenação dos transectos no campo limpo úmido. Assim, além de considerar a partição do nicho temporal como um mecanismo para a coexistência de espécies, a heterogeneidade do espaço ditada por filtros ambientais parece determinar a estabilidade destas comunidades campestres ao longo do tempo.

Palavras-chave: camada herbáceo-subarbustiva, método de interseção de linha, padrões espaciais, padrões temporais, atributos funcionais das plantas. 


\section{Introduction}

The current status of plant communities is the result of a dynamic and complex system, with more subtle changes on large time-scales (ecological and evolutionary), as a result, for example; of changes to glacial and interglacial periods (Gurevitch et al., 2009). Nevertheless, in recent decades, interest has grown by plant ecologists in the study of dynamics on shorter time intervals. One approach is to look at changes in the structure and composition of vegetation with the application of a given sampling method at different moments in time in the same community (Bakker et al., 1996). Such studies can reveal trends in community development, changes in environmental and energy flow in the ecosystem (Šamonil and Vrška, 2008), and generate answers about the stability of plant communities, and thus design future scenarios that may assist in maintaining biodiversity (Rees et al., 2001).

According to Dieckmann et al. (1999), grassland communities are a great resource for assessing spatiotemporal processes. Factors such as their relatively fast establishment, compared to shrub or forest systems, and the various threats that exist in these communities, can be the cause of accelerated dynamics (Weiher and Keddy, 1995). Studies on the dynamics of this layer of vegetation began in the $30 \mathrm{~s}$, with the investigation of annual changes in the spatial structure of communities in Breckland, England (Watt, 1960). Since then, work carried out on other sites around the world suggests generally high rates of species replacement over short time-scales (Van der Maarel and Sykes, 1993; Herben et al., 2000; Matesanz et al., 2009). This high mobility can be related to the presence of disturbances in the area whether anthropogenic or natural, such as a recurrent drought and to how the species grow (Klimeš, 1999).

The hydrologic fluctuation is one of the determinants of dynamic processes in Central Brazilian grassland areas, either by flooding or by the fluctuation of the excess soil water (Munhoz and Felfili, 2008). In permanently flooded grasslands in central Brazil there is greater stability and smaller changes are observed in the vegetation throughout the year (Cianciaruso and Batalha, 2008).

Species respond individually to environmental factors, including natural disturbances, or not, and may show different dispersal capabilities in time and space within the groups with similar functional characteristics (Huntley, 1991; Dias and Cabido, 1997). The various definitions for functional groups converge on the idea that these are composed of plants that are functionally similar regarding a given set of characteristics that respond to certain environmental variables (Box, 1996; Pillar and Sosinski-Jr, 2003). Such functional characters were defined by Violle et al. (2007) as the set of morpho-physio-phenological traits taken at the individual level. Another important issue is that species richness and functional differentiation may vary independently of each other, since the environmental filters limit species composition for a given range of functional traits (Keddy, 1992; Bello et al., 2006). Lavorel and Garnier (2002) have proposed two distinct concepts for grouping species on the basis of their traits or morphological, reproductive and physiological characteristics. The first concept, adopted in this paper, deals with traits associated with the responses of the organisms to environmental factors (biotic or abiotic), while the second concept, related to effect traits, groups species with similar effects in ecosystem functioning.

Species can display different types of spatial dynamics. They may have occurrences that are occasional (species with a low frequency in space and time), local (low frequency in space, but occurring on the same plots over time), pulsating (low or medium spatial frequency, but varying greatly from year to year), circulating (medium or high frequency, but moving and reaching high cumulative frequency) or constant (occurring in almost every part and in all years) (Van Der Maarel ,1996). Studies carried out in temperate grassland suggest that the fastest growing vegetative species are more likely to exhibit higher substitution rates over time (Rusch and Van Der Maarel, 1992).

In this context, we aim to generate information which advances the understanding of dynamic processes in grassland vegetation, assuming that the communities of moist grassland savanna are dynamic over short time. We tested the hypotheses that consider the partition of the temporal niche as a mechanism for co-existence of species with similar functional response traits (Rusch and Van Der Maarel, 1992). To this end we raised the following questions: 1) Are the fragments of moist grassland in the Sete Cidades National Park (ParnaSC) similar in vegetation composition and structure across five years (three sampling periods)? 2) What is the contribution of space and time to the structure of the community? 3) Do the species attributes form functional groups with different dynamics strategies? 4) Do the differing levels of moisture verified in these areas affect the structure of the communities? 5) Does the previous year's rainfall affect the structure of these communities?

\section{Material and Methods}

\subsection{Study site}

All field studies were conducted in fragments of grassland in a Cerrado area of the Sete Cidades National Park - ParnaSC (Figure 1). The Park has an area of $6,221.48$ ha, located in the State of Piauí, northeastern Brazil. Grassland vegetation comprises $14.3 \%$ of the park's total size (Oliveira et al., 2007). The last fire reported in the park occurred in 1996 (IBAMA, 2005).

The ParnaSC features a slightly undulating topography and altimetry ranging from 100 to $290 \mathrm{~m}$ above sea level (Oliveira et al., 2007). The weather station monitoring local climatic conditions is approximately $15 \mathrm{~km}$ from the area. According to records of the last 32 years, the average annual rainfall was $1,650 \mathrm{~mm}$, with a water surplus between February and May, and an annual average temperature of $26.7^{\circ} \mathrm{C}$, with little variation throughout the year. According to the classification of Thornthwaite and Mather (1955), the climate is sub-humid and megathermal 
with major water deficit in winter and a concentration of $30.3 \%$ of potential evapotranspiration in SeptemberOctober-November $\left(\mathrm{C}_{2} \mathrm{w}_{2} \mathrm{~A}^{\prime} \mathrm{a}^{\prime}\right)$. There was wide variation in rainfall between the years of study, $1,344 \mathrm{~mm}$ in 2007 , $2,243.8 \mathrm{~mm}$ in 2009 and $1,782.3 \mathrm{~mm}$ in 2011, as in the years before the sampling (Figure 2).

The soils in the grassland areas of the park are predominantly Quartzarenic Neosol (Quartzipsamment) and alfisols (Oliveira, 2004). In the areas of study they are strongly acidic ( $\mathrm{pH}$ ranging from 3.8 to 4.2 ), with high levels of aluminum ( 0.2 to $\left.1.0 \mathrm{cmolc}^{-\mathrm{dm}^{-3}}\right)$, low levels of macronutrients, especially $\mathrm{Ca}$ and $\mathrm{Mg}$, which amounted to around $0.3 \mathrm{cmolc} . \mathrm{dm}^{-3}$ and high iron content
(Mendes et al., 2012). We selected two subtypes of moist grassland communities in the areas studied in 2007 based on the duration of flooding (Mendes et al., 2012); in subsequent samples the moisture was measured by Soil pH-Moisture Meter (Modelo PH-2500; Instrutherm, Brazil), confirming the difference in moisture content between the drier $(\bar{x}=45.19 \%$; sd $=13.02$ in 2009 and $\bar{x}=46.06 \%$; $\mathrm{sd}=18.81$ in 2011) and moister $(\overline{\mathrm{x}}=74.27 \%$; $\mathrm{sd}=5.54$ in 2009 e $\bar{x}=76.67 \%$; sd 7.09 in 2011) fragments.

\subsection{Vegetation recording}

A total of 17 monitoring transects was established in July 2007 at the end of the rainy season. The herbaceous-shrub
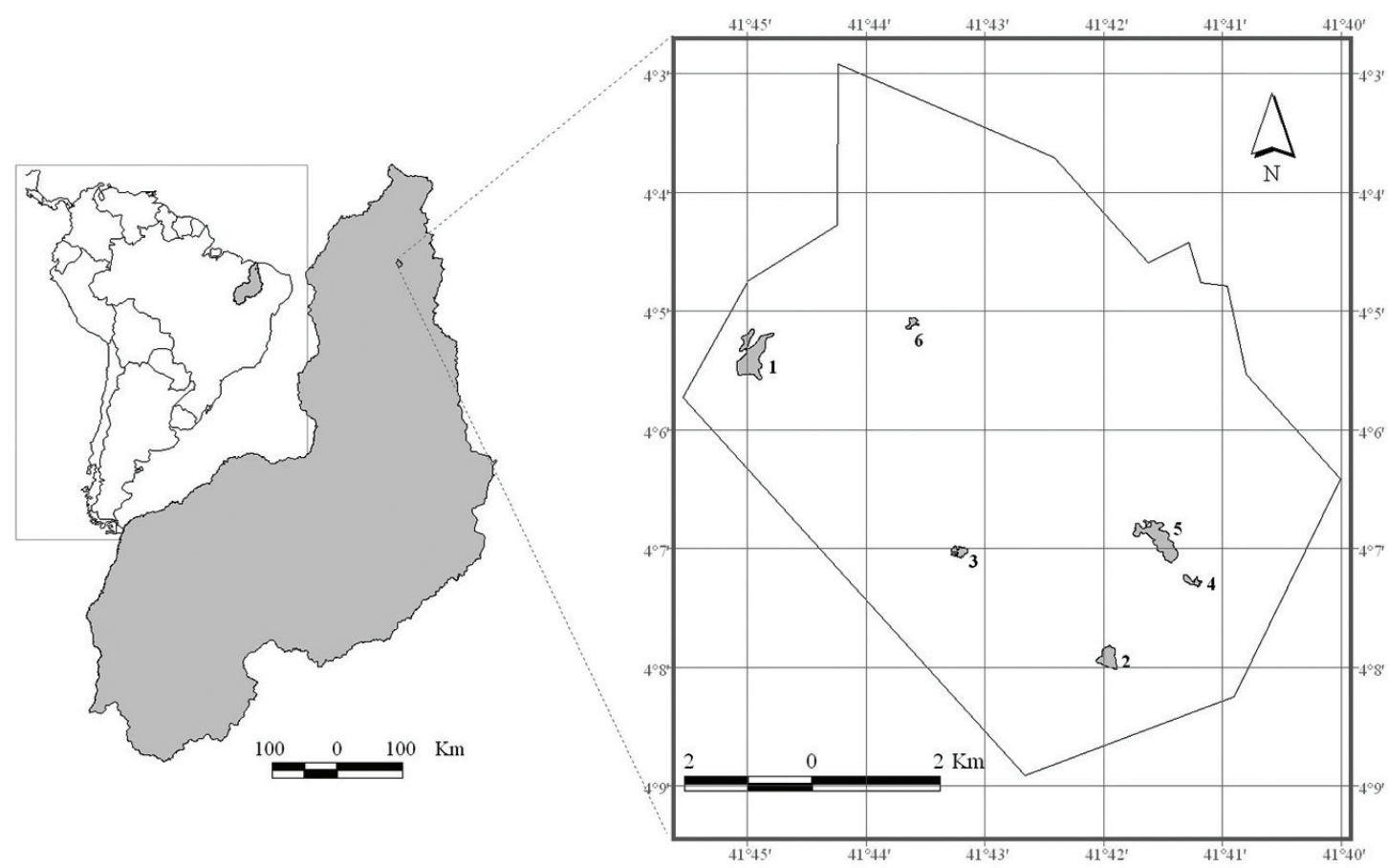

Figure 1. Geographic location of the grasslands sampled in the Sete Cidades National Park, in the north of the state of Piauí, Brazil. Area 1 (T1 - T5), Area 2 (T6 - T8), Area 3 (T9 - T11), Area 4 (T12 - T13), Area 5 (T14 - T15), Area 6 (T16 - T17). .

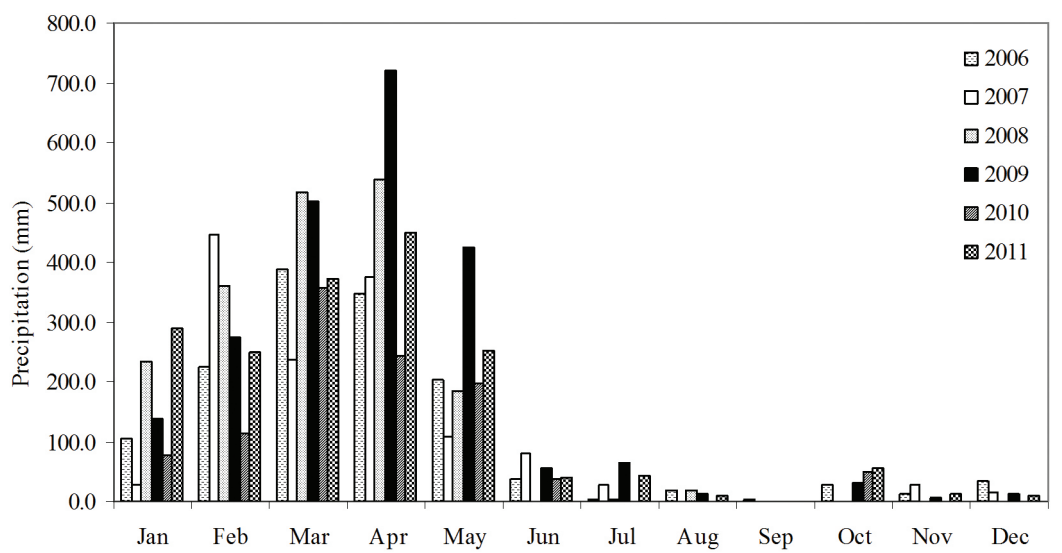

Figure 2. Monthly rainfall recorded from January 2006 to July 2011 at the weather station in Piripiri, Piauí. Data provided by the National Metereology Institute (INMET). 
vegetation was sampled using the line transect interception method (Canfield, 1941). The $10 \mathrm{~m}$ transects were distributed into six fragments with different sizes (1.2 to $19.2 \mathrm{ha}$ ) and different soil moisture content (Mendes et al., 2012). Each transect was subdivided in $1 \mathrm{~m}$ sections with iron rods. These $1 \mathrm{~m}$ sections were considered the sampling subunits for the field survey, the sum of the projection of the species in the 10 sampled subunits of each $10 \mathrm{~m}$ transect was used in the calculations for species coverage and for the analyses. The number of transects varied according to the size of the fragment of moist grassland: five in the first area, three in the second and third areas and two in the remainder (Figure 1). Area 5, albeit large, received two transects only due to the predominance of a single species and low occurrence of other species. The relative cover of each species in the $1 \mathrm{~m}$ segment were recorded for each transect, totaling $170 \mathrm{~m}$ sampled. We resampled the same transects for comparison with the first survey in July 2009 and 2011. The position of each transect was obtained through the readings of coordinates from a conventional GPS receiver on the two ends of the transect. We calculated the middle point in each of these pairs of coordinates to represent transect positioning.

\subsection{Functional plant traits}

We selected five traits with two to six states each that we assume closely related with environmental resources, pollinators and dispersers. These attributes, assessed on the basis of field observations, herbarium collections and flora, were as follows:

a) Raunkiaer's life-form categories (MuellerDombois and Ellenberg, 1974): chamaephyte (Ch), geophyte (G), therophytes (Th), herbaceous vines (Hv), holoparasites (Ho), and hemicryptophyte $(\mathrm{H})$. So as to better represent land-use strategies tussock hemicryptophytes (TH) and non-tussock hemicryptophytes (NTH) were considered;

b) Plant persistence (life history): annual (A) and perennial $(\mathrm{P})$

c) Plant height (cm): $\leq 10(\mathrm{H} 1),>10$ and $\leq 30(\mathrm{H} 2)$, > 30 and $\leq 60(\mathrm{H} 3),>60$ and $\leq 90(\mathrm{H} 4),>90(\mathrm{H} 5)$;

d) Floral traits related to the dispersal agent (Gurevitch et al., 2009), in order to infer the type of pollination, based on flower color observed in the field: without petals (P1), white or cream flowers (P2), yellow flowers (P3), blue flowers (P4), lilac, pink and purple flowers (P5), and green flowers (P6);

e) Dispersal syndromes according to Van Der Pijl (1982): wind (anemochory), animal attachment or survival in the animal digestive tract (zoochory), and self-dispersion by explosion and gravity (autochory).

\subsection{Data analysis}

Cover of the species in each $10 \mathrm{~m}$ transect in each year of sampling was used to calculate Shannon diversity index (H') and Pielou evenness (J'). The H'values for the three periods were compared with Hutcheson's t test (Zar, 1999) using the PAST software program, version 1.91 (Hammer et al., 2001).
To compare the richness potential between the surveys we used species-area accumulation curves for three periods, estimated with a first and second order Jackknife estimator using PC-ORD software, version 6.0 (McCune and Mefford, 2011). The curves were drawn from the averages and $95 \%$ confidence intervals (CI) of the cumulative number of species, considering each sampling meters as the unit of measure. Curves with overlapping CIs were not considered significantly different.

The similarity between the inventories for the total area, as well as between the drier communities (fragments one, two, four and five) and the wetter ones (three and six) (Mendes et al., 2012), were evaluated by the Chao estimator for Sørensen index, which reduces under sampling bias by estimating and compensating for the effects of unseen, shared species (Chao et al., 2005). We calculated the Chao-Sørensen index from the $95 \%$ confidence intervals (95\% CI) using the EstimateS 8.2 software (Colwell, 2006).

We used Non-Metric Dimensional Scaling (NMDS) with the Bray-Curtis distance as dissimilarity measure, the better solution in two dimensions, and criterion for stabilization $=0.00001$. According to Peck (2010), NMDS can be used to find redundant patterns in almost all types of database, and looks for answers between comparable treatments or periods of time series. Here the goal was to observe variation in the ordering of transects in the three sampling times. Our assumption was that samples assessed in 2007, 2009, and 2011 with similar species and cover composition would occur on the same point in the ordination diagram. We also tested the difference between the groups formed in NMDS ordination by using Multi-response Permutation Procedures (MRPP) with a Bray-Curtis distance measure, recommended for heterogeneous data (Peck, 2010).

To define the functional groups, considering the trait state selected for this study, a hierarchical, agglomerative and polythetic clustering analysis based on Bray-Curtis distances was used. This method is adequate to identify groups of sampling units or species that are similar in composition or strategies (Peck, 2010). The matrix was composed of 92 species and 23 trait state using the BrayCurtis distance and the groups average as a connection method. To see the distribution of the sample transects in the three periods based on the abundance of functional groups, the next step was to produce the AG' matrix (sampling transects $\mathrm{x}$ functional groups) by the multiplication of two matrices: 1) matrix A: species $\times$ sampling transects (species coverage data); and 2) matrix G: functional groups $\times$ species (binary matrix). Because matrix $\mathrm{G}$ is composed of little heterogeneous data (13.7\% of zeros; mean inclination of the variables $=1.9$ and total coefficient of variation $(\mathrm{CV})$ of transects $=22.5 \%$ ), we used the principal components analysis (PCA). Multivariate analyses were performed using the PCORD program version 6.0 (McCune and Mefford, 2011).

To determine whether there is significant difference in the coverage of functional groups between sampling times $(2007,2009$, and 2011) we used the permutational 
multivariate analysis of variance (PerMANOVA) (Anderson, 2001). The analysis was done by using PCORD version 6.0 (McCune and Mefford, 2011), with each time considered as a treatment and the distance measure by Bray-Curtis's.

To distinguish the contribution of space and time configuration in the community structure, we used the variance partition technique described in Peres-Neto et al. (2006), with the data for geographical coordinates and sampling years synthesized by means of Moran's Eigenvector Maps (MEM) (Dray et al., 2006). The first step consists in obtaining the best spatial matrix for the set of data under analysis. To this end, we reproduced several linking matrices representing hypotheses of which sampling lines are perceived as having some degree of dependence. We used distance as a linkage criterion, resulting in linking matrices with maximum distances ranging from the minimum required to keep all points connected (greatest distance in a minimum spanning tree) to the distance in which data are observed independent in a multivariate variogram. For each of these binary descriptors of the potential influence of a sampling line over another, we used functions representing the reduction in influence that one point would have over another as distance increases. The distance functions followed the recommendations in Dray et al. (2006), using linear, concave down and concave up weighting functions. For each of these combinations an MEM was generated. Subsequently, we verified which of the options yielded the best adjustment with the abundance data for the three species. To this end, we performed the Hellinger transformation in the community matrix (following the recommendation of Legendre and Gallagher (2001)), and subsequently removed linear trends. Next, we calculated a multivaried extension following the Akaike Information criterion (Godinez-Dominguez and Freire, 2003) so as to select the best spatial matrix (the combination of best linking matrix, best weighting function, and best number of autovectors). To produce the temporal matrix, we followed a similar procedure, but due to there having been only three years of sampling, we simplified the procedure so as to take on only the function of linear linkage. The resulting matrix of temporal relationships comprised two orthogonal columns that may be construed as a temporal trend and a cyclical fluctuation. Thenceforth we performed the analysis of variance partition of the community pattern (through Hellinger's transformation), explained by the spatial matrix and by the temporal matrix, by means of the partial redundancy analysis (partial RDA). We performed an analysis after removing the temporal effect in order to verify the spatial effect only and an analysis without the spatial effect to verify the temporal effect only, followed by Monte Carlo tests to gauge the significance of each relationship. The values of the redundancy statistical fractions were adjusted to make up for the effect of the number of variables and samples in these figures, arriving at an indicator resembling an adjusted $\mathrm{R}^{2}$. Additionally, we verified the influence of the previous year's rainfall on the community at each sampling, removing the space effect and the effect of average soil moisture in each line (average values obtained in 2009 and 2011), removing the space and time effects. In this case, we used the spatial and temporal matrices described previously and carried out the variation partitioning described above. All the procedures were performed through Vegan version 2.0-5 (Oksanen et al., 2012), SpacemakeR version 0.0-5/r101 (Dray et al., 2006) packages, implemented in R software version 2.15.2 (R Foundation for Statistical Computing, Vienna).

\section{Results}

The number of species in the 2009 and 2011 inventories was higher than that in 2007. A total of 28 families, 56 genera, and 92 species were recorded, of which 58 species were common in all three samples (Table 1). The richest families were the same across the periods (Table 1). The increase in richness raised the values in the Shannon index, which were significantly different in all comparisons, and in Pielou's evenness (Table 2). The species-area curves (Figure 3), featuring significant differences in all comparisons in the confidence interval analysis $(95 \% \mathrm{CI})$, and jackknife estimator of species richness (Table 2) confirmed the trend of increasing species in 2009 and 2011.

Nevertheless, the number of species in common $(63 \%)$ contributed to high similarity between inventories for the total sample $(95 \%$ CI of 2007 and $2009=0.97,0.99$; 2007 and $2011=0.97,0.99 ; 2009$ and $2011=0.98,1.00$ ), as well as when the analysis was performed for the two subtypes found on the moist ParnaSC grassland's, wetter areas $(95 \%$ CI of 2007 and $2009=0.95,0.99 ; 2007$ and $2011=0.93,0.99 ; 2009$ and $2011=0.92,1.00)$ and drier ones $(95 \% \mathrm{CI}$ of 2007 and $2009=0.96,1.00 ; 2007$ and $2011=0.94,0.98 ; 2009$ and $2011=0.94,1.00)$.

The distances between sample units in the space of ordination of NMDS based on species composition and cover, formed three groups of sampling transects that reflected the differences in soil characteristics, especially the moisture (Figure 4). The first group, on the right of the diagram, constituted moist areas (three and six) and transect five (2007 and 2011); the other two groups on the left brought together the drier areas, with T3 and T4 transects separated from the others. As tested with MRPP, the transects form distinct, spatially varied groups $(\mathrm{A}=0.29, \mathrm{p}<0.0001)$. This ordination model not making group separation according to sampling times $(2007,2009$ and 2011), while identifying moderate associations with modifications occurring in the transects over time, with the largest dissimilarity occurring in T4, T5, T6, T7, T8 and T11 (Figure 4).

The cluster analysis formed seven functional groups of species brought together on the basis of common attributes (Table 2). The attributes related to the life history of species divided two groups, separated primarily by Raunkiaer's classes of life forms, as well as by the investment in plant height and types of diaspore dispersal (Table 3). Similar patterns of functional specialization were detected in the PCA ordination diagram between the transects in the three 
Table 1. Sampled species from the grassland areas of the Sete Cidades National Park, Piauí, in the three family inventories in alphabetical order. LV = Raunkiaer's life forms; LH = Life history; Hei = Height categories; Fl = Flower traits; DS = Dispersion syndrome. See topic "Functional species classification" in the methodology for further caption details. * Species sampled only in 2007, \# only in 2009 and + only in 2011.

\begin{tabular}{|c|c|c|c|c|c|c|c|c|c|}
\hline \multirow{2}{*}{ Family } & \multirow{2}{*}{ Species } & \multirow{2}{*}{$\mathbf{L V}$} & \multirow{2}{*}{ LH } & \multirow{2}{*}{ Hei } & \multirow{2}{*}{ Fl } & \multirow{2}{*}{ DS } & \multicolumn{3}{|c|}{ Relative coverage } \\
\hline & & & & & & & 2007 & 2009 & 2011 \\
\hline \multirow[t]{2}{*}{ Asteraceae } & Aspilia attenuata (Gardn.) Baker & NTH & $\mathrm{P}$ & H4 & P3 & zoo & 0.40 & 0.05 & 0.00 \\
\hline & Elephantopus hirtiflorus DC. & NTH & $\mathrm{P}$ & H5 & P2 & zoo & 1.78 & 2.24 & 1.47 \\
\hline Burmanniaceae & $\begin{array}{l}\text { Burmannia capitata (Walter ex J.F. Gmel.) } \\
\text { Mart. }\end{array}$ & Th & A & $\mathrm{H} 2$ & $\mathrm{P} 2$ & ane & 0.13 & 0.20 & 0.13 \\
\hline \multirow[t]{3}{*}{ Convolvulaceae } & Cuscuta partita Choisy & HP & $\mathrm{P}$ & $\mathrm{H} 2$ & P2 & zoo & 2.28 & 5.52 & 2.04 \\
\hline & Evolvulus gypsophiloides Moric. & NTH & $\mathrm{P}$ & H3 & P5 & aut & 1.66 & 2.01 & 1.13 \\
\hline & Jacquemontia montana (Moric.) Meins & $\mathrm{Hv}$ & $\mathrm{P}$ & $\mathrm{H} 4$ & P3 & aut & 0.08 & 0.00 & 0.17 \\
\hline \multirow[t]{12}{*}{ Cyperaceae } & Bulbostylis conifera (Kunth) CB. Clarke & Th & A & $\mathrm{H} 2$ & P1 & aut & 0.21 & 0.10 & 0.02 \\
\hline & Eleocharis barrosii Svenson & Th & A & H1 & P1 & aut & 0.18 & 0.39 & 0.18 \\
\hline & Rhynchospora barbata (Vahl) Kunth & TH & $\mathrm{P}$ & $\mathrm{H} 4$ & $\mathrm{P} 1$ & aut & 9.75 & 5.55 & 12.50 \\
\hline & Rhynchospora aff. candida (Nees) Boeck. & Th & A & H3 & P1 & aut & 0.00 & 0.46 & 0.05 \\
\hline & Rhynchospora filiformis Vahl & HT & $\mathrm{P}$ & H3 & $\mathrm{P} 1$ & aut & 0.06 & 0.26 & 0.69 \\
\hline & Rhynchospora hirsuta (Vahl) Vahl & Th & A & $\mathrm{H} 3$ & P1 & aut & 0.90 & 0.29 & 0.35 \\
\hline & Rhynchospora riparia (Nees) Boeck & $\mathrm{TH}$ & $\mathrm{P}$ & $\mathrm{H} 3$ & P1 & aut & 3.73 & 3.71 & 3.13 \\
\hline & Rhynchospora rugosa (Vahl) Galé* & $\mathrm{TH}$ & $\mathrm{P}$ & H5 & P1 & aut & 0.58 & 0.00 & 0.00 \\
\hline & Rhynchospora tenella (Nees) Boeck. & Th & A & $\mathrm{H} 3$ & $\mathrm{P} 1$ & aut & 0.00 & 1.32 & 0.12 \\
\hline & Rhynchospora tenerrima Nees ex Spreng. & Th & A & H3 & $\mathrm{P} 1$ & aut & 0.00 & 0.08 & 0.12 \\
\hline & Scleria leptostachya Kunth & NTH & $\mathrm{P}$ & H3 & $\mathrm{P} 1$ & aut & 1.68 & 1.45 & 1.00 \\
\hline & Scleria reticularis Michx. ex Willd. & NTH & $\mathrm{P}$ & H4 & P1 & aut & 1.82 & 1.57 & 0.99 \\
\hline \multirow{5}{*}{$\begin{array}{l}\text { Droseraceae } \\
\text { Eriocaulaceae }\end{array}$} & Drosera sessilifolia A. St.-Hil. & Th & A & $\mathrm{H} 2$ & P5 & ane & 0.50 & 0.49 & 0.54 \\
\hline & $\begin{array}{l}\text { Paepalanthus manicatus V.A.Pouls ex } \\
\text { Malme. }\end{array}$ & Th & A & 1 & P1 & ane & 0.25 & 0.61 & 0.82 \\
\hline & Syngonanthus cf. gracilis (Bong.) Ruhland* & Th & A & H1 & $\mathrm{P} 1$ & ane & 0.05 & 0.00 & 0,00 \\
\hline & Syngonanthus cf. nitens (Bong.) Ruhland & Th & A & $\mathrm{H} 2$ & P1 & ane & 0.18 & 0.27 & 0.09 \\
\hline & Syngonanthus sp. & Th & A & H1 & $\mathrm{P} 1$ & ane & 0.45 & 0.76 & 0.004 \\
\hline \multirow{9}{*}{$\begin{array}{l}\text { Euphorbiaceae } \\
\text { Fabaceae }\end{array}$} & Croton pedicellatus Kunth. & $\mathrm{Ch}$ & $\mathrm{P}$ & $\mathrm{H} 2$ & P2 & aut & 0.82 & 0.46 & 0.48 \\
\hline & Aeschynomene americana $\mathrm{L}$. & NTH & $\mathrm{P}$ & H5 & P3 & aut & 0.07 & 0.02 & 0.05 \\
\hline & $\begin{array}{l}\text { Chamaecrista desvauxii var. chapadicola } \\
\text { H.S.Irwin \& Barneby }\end{array}$ & $\mathrm{Ch}$ & $\mathrm{P}$ & $\mathrm{H} 4$ & P3 & aut & 1.04 & 2.23 & 1.65 \\
\hline & Chamaecrista diphylla (L.) Greene & $\mathrm{Ch}$ & $\mathrm{P}$ & $\mathrm{H} 2$ & P3 & aut & 0.45 & 0.53 & 0.33 \\
\hline & $\begin{array}{l}\text { Chamaecrista flexuosa (L.) Greene var. } \\
\text { flexuosa }\end{array}$ & $\mathrm{Ch}$ & $\mathrm{P}$ & H5 & P3 & aut & 0.82 & 1.36 & 0.07 \\
\hline & $\begin{array}{l}\text { Chamaecrista linearis var. modesta } \\
\text { (H.S.Irwin \& Barneby) Fernandes \& } \\
\text { Nunes }\end{array}$ & $\mathrm{Ch}$ & $\mathrm{P}$ & $\mathrm{H} 3$ & P3 & aut & 0.04 & 0.004 & 0.05 \\
\hline & Mimosa hypoglauca Mart. & $\mathrm{Ch}$ & $\mathrm{P}$ & $\mathrm{H} 3$ & P5 & zoo & 2.44 & 2.68 & 1.80 \\
\hline & Mimosa somnians Humb. \& Bonpl. ex Willd & $\mathrm{Ch}$ & $\mathrm{P}$ & H5 & P5 & zoo & 0.21 & 0.39 & 0.61 \\
\hline & Stylosanthes angustifolia Vogel & NTH & $\mathrm{P}$ & H3 & P3 & aut & 2.08 & 2.09 & 1.45 \\
\hline \multirow[t]{4}{*}{ Gentianaceae } & Curtia tenella (Mart.) Cham. & Th & A & $\mathrm{H} 3$ & $\mathrm{P} 2$ & zoo & 0.04 & 0.06 & 0.19 \\
\hline & Curtia tenuifolia (Aubl.) Knobl. & Th & A & H3 & P5 & zoo & 0.06 & 0.00 & 0.03 \\
\hline & Schultesia benthamiana Klotzsch ex Griseb.\# & Th & A & $\mathrm{H} 2$ & P3 & aut & 0.00 & 0.02 & 0.00 \\
\hline & Schultesia pohliana Progel & Th & A & $\mathrm{H} 2$ & P5 & aut & 0.00 & 0.04 & 0.01 \\
\hline Krameriaceae & Krameria grandiflora A.St.-Hil. & NTH & $\mathrm{P}$ & H1 & P5 & zoo & 0.07 & 0.31 & 0.004 \\
\hline \multirow[t]{4}{*}{ Lamiaceae } & Eriope sp. & NTH & $\mathrm{P}$ & H3 & P5 & aut & 0.97 & 0.54 & 0.71 \\
\hline & Hyptis atrorubens Poit. & NTH & $P$ & $\mathrm{H} 4$ & $\mathrm{P} 2$ & aut & 0.33 & 0.04 & 0.14 \\
\hline & Hyptis crenata Pohl \& Benth. & $\mathrm{Ch}$ & $\mathrm{P}$ & $\mathrm{H} 3$ & P4 & aut & 0.23 & 0.12 & 0.42 \\
\hline & Marsypianthes sp.+ & NTH & $P$ & $\mathrm{H} 2$ & P5 & Aut & 0.00 & 0.00 & 0.02 \\
\hline \multirow[t]{2}{*}{ Lentibulariaceae } & $\begin{array}{l}\text { Utricularia amethystina Salzm. ex A. St.- } \\
\text { Hil. \& Girard }{ }^{\#}\end{array}$ & Th & A & $\mathrm{H} 2$ & P5 & ane & 0.00 & 0.12 & 0.00 \\
\hline & Utricularia cucullata A.St.-Hil. \& Girard & Th & $\mathrm{A}$ & $\mathrm{H} 1$ & P5 & ane & 0.00 & 0.02 & 0.01 \\
\hline
\end{tabular}


Table 1. Continued...

\begin{tabular}{|c|c|c|c|c|c|c|c|c|c|}
\hline \multirow{2}{*}{ Family } & \multirow{2}{*}{ Species } & \multirow{2}{*}{$\mathbf{L V}$} & \multirow{2}{*}{$\mathbf{L H}$} & \multirow{2}{*}{ Hei } & \multirow{2}{*}{ Fl } & \multirow{2}{*}{ DS } & \multicolumn{3}{|c|}{ Relative coverage } \\
\hline & & & & & & & 2007 & 2009 & 2011 \\
\hline & Utricularia simulans Pilg. & Th & $\mathrm{A}$ & $\mathrm{H} 2$ & P3 & ane & 0.02 & 0.05 & 0.06 \\
\hline & Utricularia subulata L. & Th & A & $\mathrm{H} 2$ & P3 & ane & 0.24 & 0.94 & 0.05 \\
\hline Lycopodiaceae & Lycopodiella alopecuroides (L.) Cranfill+ & Th & A & H3 & - & ane & 0.00 & 0.00 & 0.07 \\
\hline Lythraceae & Cuphea laricoides Koehne & $\mathrm{Ch}$ & $\mathrm{P}$ & H3 & P2 & aut & 0.14 & 0.01 & 0.21 \\
\hline \multirow[t]{3}{*}{ Malvaceae } & Sida linifolia Cav. & NTH & $\mathrm{P}$ & $\mathrm{H} 4$ & $\mathrm{P} 2$ & aut & 0.01 & 0.02 & 0.01 \\
\hline & Sida sp.+ & $\mathrm{NTH}$ & $\mathrm{P}$ & $\mathrm{H} 4$ & P3 & aut & 0.00 & 0.00 & 0.03 \\
\hline & Sida viarum A. St.-Hil. & $\mathrm{NTH}$ & $\mathrm{P}$ & $\mathrm{H} 2$ & P5 & aut & 0.01 & 0.06 & 0.04 \\
\hline \multirow[t]{5}{*}{ Melastomataceae } & Acisanthera bivalvis (Aubl.) Cogn. & NTH & $\mathrm{P}$ & $\mathrm{H} 3$ & P5 & zoo & 0.26 & 0.30 & 0.96 \\
\hline & Acisanthera fluitans Cogn & Th & A & $\mathrm{H} 2$ & $\mathrm{P} 2$ & zoo & 0.15 & 0.01 & 0.15 \\
\hline & Desmoscelis villosa (Aubl.) Naudin ${ }^{\#}$ & $\mathrm{Ch}$ & $\mathrm{P}$ & $\mathrm{H} 4$ & P5 & aut & 0.00 & 0.004 & 0.00 \\
\hline & Pterolepis polygonoides (DC.) Triana & NTH & $\mathrm{P}$ & H3 & P5 & aut & 1.15 & 0.49 & 1.03 \\
\hline & Rhynchanthera grandiflora (Aubl.) DC. & $\mathrm{Ch}$ & $\mathrm{P}$ & H5 & P5 & aut & 7.37 & 7.04 & 10.51 \\
\hline \multirow[t]{2}{*}{ Ochnaceae } & Sauvagesia erecta $\mathrm{L}$. & $\mathrm{NTH}$ & $\mathrm{P}$ & $\mathrm{H} 3$ & $\mathrm{P} 2$ & zoo & 0.19 & 0.34 & 0.75 \\
\hline & Sauvagesia tenella Lam. & Th & A & H1 & P5 & zoo & 0.00 & 0.06 & 0.02 \\
\hline \multirow[t]{2}{*}{ Orchidaceae } & Habenaria spathulifera Cogn. & G & $\mathrm{P}$ & $\mathrm{H} 3$ & P3 & ane & 0.04 & 0.03 & 0.00 \\
\hline & Habenaria sprucei Cogn.\# & G & $\mathrm{P}$ & H3 & P6 & ane & 0.00 & 0.004 & 0.00 \\
\hline Orobanchaceae & Buchnera palustris (Aubl.) Spreng.+ & NTH & $\mathrm{P}$ & H3 & P5 & Aut & 0.00 & 0.00 & 0.02 \\
\hline Oxalidaceae & Oxalis divaricata Mart. ex Zucc. & NTH & $\mathrm{P}$ & H3 & P3 & aut & 0.03 & 0.01 & 0.03 \\
\hline \multirow[t]{3}{*}{ Passifloraceae } & Piriqueta plicata Urb. & $\mathrm{Ch}$ & $\mathrm{P}$ & H3 & P3 & ane & 0.07 & 0.06 & 0.05 \\
\hline & Turnera caerulea DC. & NTH & $\mathrm{P}$ & H3 & $\mathrm{P} 2$ & aut & 0.07 & 0.07 & 0.27 \\
\hline & Turnera oblongifolia Cambess. & $\mathrm{NTH}$ & $\mathrm{P}$ & H3 & P3 & aut & 0.21 & 0.41 & 0.43 \\
\hline Phyllanthaceae & Phyllanthus sp. & $\mathrm{Th}$ & A & $\mathrm{H} 2$ & P6 & ane & 0.01 & 0.01 & 0.00 \\
\hline \multirow[t]{3}{*}{ Plantaginaceae } & Bacopa angulata (Benth.) Edwall & NTH & $\mathrm{P}$ & H3 & P5 & aut & 0.004 & 0.03 & 0.004 \\
\hline & Bacopa sp.+ & $\mathrm{Th}$ & A & $\mathrm{H} 2$ & P5 & aut & 0.00 & 0.00 & 0.09 \\
\hline & Tetraulacium veroniciforme Turcz. & Th & A & $\mathrm{H} 3$ & P6 & aut & 0.00 & 0.05 & 0.05 \\
\hline \multirow[t]{9}{*}{ Poaceae } & Andropogon selloanus (Hack.) Hack. & TH & $\mathrm{P}$ & H5 & $\mathrm{P} 1$ & ane & 0.00 & 0.08 & 1.15 \\
\hline & Axonopus purpusii (Mez) Chase & $\mathrm{TH}$ & $\mathrm{P}$ & $\mathrm{H} 4$ & $\mathrm{P} 1$ & zoo & 2.09 & 3.78 & 1.05 \\
\hline & $\begin{array}{l}\text { Mesosetum loliiforme (Hochst. ex Steud.) } \\
\text { Chase }\end{array}$ & $\mathrm{TH}$ & $\mathrm{P}$ & $\mathrm{H} 4$ & $\mathrm{P} 1$ & zoo & 6.62 & 3.31 & 9.86 \\
\hline & Mesosetum sp. nov. & $\mathrm{TH}$ & $\mathrm{P}$ & $\mathrm{H} 4$ & $\mathrm{P} 1$ & zoo & 2.32 & 2.04 & 5.35 \\
\hline & Paspalum multicaule Poir & Th & A & $\mathrm{H} 2$ & $\mathrm{P} 1$ & zoo & 2.28 & 1.10 & 2.20 \\
\hline & Paspalum rojasii Hack. & $\mathrm{TH}$ & $\mathrm{P}$ & H5 & $\mathrm{P} 1$ & zoo & 0.00 & 0.33 & 0.16 \\
\hline & Sacciolepis vilvoides (Trin.) Chase & Th & A & H5 & $\mathrm{P} 1$ & zoo & 2.07 & 1.44 & 0.45 \\
\hline & Steirachne barbata (Trin.) Renvoize & Th & A & $\mathrm{H} 3$ & $\mathrm{P} 1$ & zoo & 4.29 & 4.36 & 4.66 \\
\hline & Trachypogon spicatus (L. f.) Kuntze & TH & $\mathrm{P}$ & H5 & $\mathrm{P} 1$ & zoo & 31.72 & 31.71 & 21.16 \\
\hline \multirow[t]{5}{*}{ Polygalaceae } & Polygala celosioides Mart. & Th & A & H3 & P2 & zoo & 0.07 & 0.03 & 0.00 \\
\hline & Polygala longicaulis Kunth* & $\mathrm{Th}$ & A & $\mathrm{H} 3$ & P5 & zoo & 0.004 & 0.00 & 0.00 \\
\hline & Polygala savannarum Chodat $^{\#}$ & $\mathrm{Th}$ & A & $\mathrm{H} 2$ & $\mathrm{P} 3$ & zoo & 0.00 & 0.01 & 0.00 \\
\hline & Polygala sedoides A. W. Benn* & Th & A & $\mathrm{H} 1$ & $\mathrm{P} 2$ & zoo & 0.07 & 0.00 & 0.00 \\
\hline & Polygala subtilis Kunth* & Th & A & $\mathrm{H} 2$ & $\mathrm{P} 2$ & zoo & 0.03 & 0.00 & 0.00 \\
\hline \multirow[t]{5}{*}{ Rubiaceae } & Borreria densiflora DC.* & NTH & $\mathrm{P}$ & H5 & $\mathrm{P} 2$ & aut & 0.004 & 0.00 & 0.00 \\
\hline & Borreria scabiosoides Cham. \& Schltdl. & NTH & $\mathrm{P}$ & $\mathrm{H} 4$ & $\mathrm{P} 2$ & aut & 0.04 & 0.004 & 0.00 \\
\hline & $\begin{array}{l}\text { Diodella apiculata (Willd. ex Roen.\& } \\
\text { Schult.) Delprete }\end{array}$ & Th & A & $\mathrm{H} 2$ & P5 & aut & 0.08 & 0.03 & 0.23 \\
\hline & Limnosipanea schomburgkii Hook. f. & $\mathrm{Th}$ & A & $\mathrm{H} 2$ & $\mathrm{P} 2$ & zoo & 0.12 & 0.37 & 0.09 \\
\hline & $\begin{array}{l}\text { Staelia virgata (Willd. ex Roem. \& } \\
\text { Schult.) K. Schum }\end{array}$ & $\mathrm{NTH}$ & $\mathrm{P}$ & $\mathrm{H} 3$ & $\mathrm{P} 2$ & aut & 0.00 & 0.05 & 0.02 \\
\hline \multirow[t]{4}{*}{ Selaginellaceae } & Selaginella sp.+ & $\mathrm{Th}$ & A & $\mathrm{H} 1$ & - & ane & 0.00 & 0.00 & 0.98 \\
\hline & Xyris guianensis Steudel & Th & A & $\mathrm{H} 2$ & P3 & aut & 0.46 & 0.45 & 0.38 \\
\hline & Xyris jupicai Rich & Th & A & H3 & P3 & aut & 0.08 & 0.20 & 1.43 \\
\hline & Xyris paraensis Poeppig ex Kunth & Th & A & H3 & P3 & aut & 0.68 & 0.97 & 0.96 \\
\hline Xyridaceae & Xyris savanensis Miq. & Th & A & H3 & P3 & aut & 0.65 & 1.40 & 1.47 \\
\hline
\end{tabular}


Table 2. Richness and diversity of six grassland areas sampled in the Sete Cidades National Park, Piauí.

\begin{tabular}{|c|c|c|c|c|c|c|c|}
\hline & $\begin{array}{l}\text { Total } \\
\text { area }\end{array}$ & $\begin{array}{c}\text { Area } \\
1 \\
\end{array}$ & $\begin{array}{c}\text { Area } \\
2 \\
\end{array}$ & $\begin{array}{c}\text { Area } \\
\mathbf{3} \\
\end{array}$ & $\begin{array}{c}\text { Area } \\
4 \\
\end{array}$ & $\begin{array}{c}\text { Area } \\
\mathbf{5} \\
\end{array}$ & $\begin{array}{c}\text { Area } \\
6 \\
\end{array}$ \\
\hline $\mathrm{N}^{\circ}$ of species $(2007)$ & 71 & 35 & 29 & 34 & 32 & 24 & 28 \\
\hline $\mathrm{N}^{\mathrm{o}}$ of species (2009) & 79 & 43 & 31 & 32 & 34 & 31 & 31 \\
\hline $\mathrm{N}^{\mathrm{o}}$ of species $(2011)$ & 76 & 43 & 35 & 34 & 31 & 28 & 27 \\
\hline Shannon (H') 2007 & 2.84 & 2.50 & 1.63 & 2.32 & 1.98 & 1.65 & 1.97 \\
\hline Shannon (H') 2009 & 2.98 & 2.70 & 1.87 & 2.52 & 1.75 & 1.79 & 2.37 \\
\hline Shannon (H') 2011 & 3.01 & 2.58 & 2.50 & 2.11 & 2.31 & 1.97 & 2.13 \\
\hline t of Hutcheson 2007 and 2009* & -7.39 & -9.55 & -7.05 & -7.19 & 4.79 & -2.94 & -12.13 \\
\hline t of Hutcheson 2007 and 2011* & -11.77 & -3.75 & -25.65 & 8.09 & -8.10 & -7.09 & -4.64 \\
\hline t of Hutcheson 2009 and 2011* & -3.60 & 5.56 & -18.55 & 14.44 & -12.34 & -3.73 & 7.52 \\
\hline Evenness (J') 2007 & 0.67 & 0.70 & 0.48 & 0.66 & 0.57 & 0.52 & 0.60 \\
\hline Evenness (J') 2009 & 0.68 & 0.75 & 0.54 & 0.73 & 0.49 & 0.52 & 0.69 \\
\hline Evenness (J') 2011 & 0.69 & 0.69 & 0.70 & 0.60 & 0.67 & 0.59 & 0.64 \\
\hline Jackknife, $1^{\mathrm{a}}$ order 2007 & - & 41.9 & 34.8 & 40.8 & 40.5 & 27.8 & 33.7 \\
\hline Jackknife, $2^{\mathrm{a}}$ order 2007 & - & 48.6 & 38.6 & 43.7 & 46.9 & 28.8 & 38.2 \\
\hline Jackknife, $1^{\mathrm{a}}$ order 2009 & - & 46.9 & 38.7 & 37.8 & 41.6 & 36.7 & 36.7 \\
\hline Jackknife, $2^{\mathrm{a}}$ order 2009 & - & 45.1 & 43.5 & 40.7 & 45.4 & 37.8 & 41.2 \\
\hline Jackknife, $1^{\mathrm{a}}$ order 2011 & - & 48.88 & 44.66 & 38.83 & 31.95 & 32.75 & 31.75 \\
\hline Jackknife, $2^{\mathrm{a}}$ order 2011 & - & 48.05 & 53.09 & 38.99 & 28.58 & 32.98 & 34.54 \\
\hline
\end{tabular}

*All combinations of values were significant differences.

sampling times (Figure 5). The first axis of PCA explained $37.59 \%$ of the variation in the data, separating groups of chamaephyte (FG3) and therophytes II (FG7) on the lefthand side of the diagram with transects associated with wetter grassland areas, except T10 and T11 (2007). On the right-hand side, the driest areas were assembled by highest correlation with the non-tussock hemicriptophytes and autochoric (FG1), tussock hemicriptophytes (FG4) and geophytes (FG5). The second PCA axis explained $19.33 \%$ of data variation and was associated with nontussock hemicriptophytes and zoochorous (FG2) and therophytes I (FG6), dictating the ordering of transects T1 (2007), T2 (2007, 2009, and 2011) and T12 (2011). The PerMANOVA found no significant differences in comparisons of the functional groups based on the cover across time $(\mathrm{F}=0.63816 ; \mathrm{p}>0.05)$.

The pattern of species coverage was primarily explained by the spatial relationship of the sampling lines. When we partitioned the variation of the coverage pattern with spatial and temporal structure, $\mathrm{R}_{\text {adjusted }}^{2}=0.584(\mathrm{p}<0.001)$ and $\mathrm{R}_{\text {adjusted }}^{2}=0.013(\mathrm{p}=0.040)$ respectively. When we assessed the temporal pattern seen as the rainfall values for the year prior to each sampling, we noted an equivalent variation value, explained by the temporal matrix (space effect after the removal of the precipitation effect: $\mathrm{R}^{2}$ adjusted $=0.572$; precipitation effect after removal of the space effect $\left.\mathrm{R}_{\text {adjusted }}^{2}=0.014\right)$. The effect of soil moisture on the plant community, considering the space and time effects, shows a small unique contribution from this variable $\left(\mathrm{R}^{2}{ }_{\text {adjusted }}=0.019\right.$; $p=0.005)$. Yet, a shared variation between moisture and space (environment spatially structured) explained an important share of the variation in the community's data $\left(\mathrm{R}^{2}\right.$ adjusted $=0.230$; the significance of this fraction cannot be tested). The highest explained fraction was related to a unique contribution of the spatial structure $\left(\mathrm{R}^{2}\right.$ adjusted $=0.354$; $\mathrm{p}<0.001)$ and the lowest fraction to the temporal structure $\left(\mathrm{R}_{\text {adjusted }}^{2}=0.015 ; \mathrm{p}=0.015\right)$. By observing the relationship between the coverage of the species and the availability of moisture, removing only the temporal effect (that is, maintaining the environmental effect and environment spatially structured: $\mathrm{R}_{\text {adjusted }}^{2}=0.249 ; \mathrm{p}<0.001$ ), we noted that Trachypogon spicatus presented a greater association to dryer environments than the remaining species and that Mesosetum loliiforme and Rhynchanthera grandiflora were more often associated with wetter environments than the remainder (Figure 6).

\section{Discussion}

Several disturbances may directly influence the dynamics of herbaceous plant communities. In moist grassland specifically, factors such as eutrophication, change in flooding regime, invasion of exotic plants, among others, are constant threats (Weiher and Keddy, 1995). Nowadays, the increasingly rapid rate of human impacts on the environment has imposed changes in natural processes, and understanding the models of community development is the first step to generating future scenarios that may assist in biodiversity maintenance (Rees et al., 2001).

We did not find great changes in the community descriptors between 2007, 2009, and 2011 for the vegetation of moist grassland savanna in the Sete Cidades National Park. In the three sampling occasions few species accounted for most of the coverage rates, which has been common in areas of moist and dry grassland and shrubgrassland in Brazil (Guimarães et al., 2002; Munhoz and Felfili, 2008; 

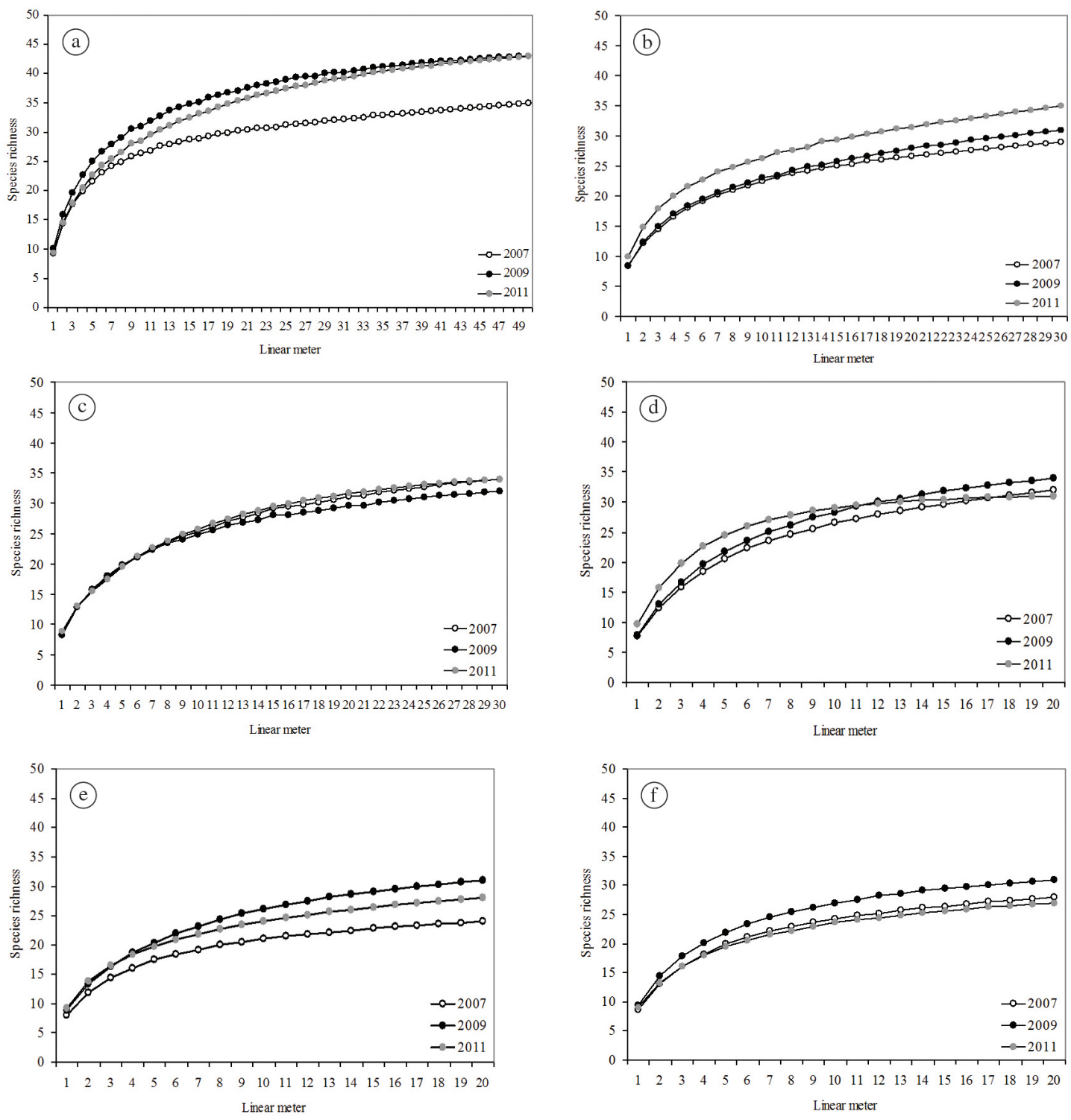

Figure 3. Progression curves of the average number of species, with sample unit increments (linear meter), for the grassland areas sampled in the Sete Cidades National Park, Piauí. (a) Area 1. (b) Area 2. (c) Area 3. (d) Area 4; (e) Area 5. (f) Area 6. For improved visualization, curves representing confidence intervals at $95 \%$ are not shown in the graphs.

Eugênio et al., 2011). The maintenance of the structure of the grassland fragments resulted in low variation in the values of evenness between years and the high similarity between the areas by the Chao-Sørensen index. But because of the occurrence of exclusive species in the inventories, there were significant differences between the values of diversity from year to year.

The seeming stability condition in the fields of ParnaSC could be related to the absolute absence of human disturbance in the region between 2007 and 2011, mainly because they comprise a protected conservation area. With regard to weather, 2007 was characterized by moderate El Nino activity, according to data from the Brazilian National Institute for Space Research (http://enos.cptec.inpe.br/tab_elnino. shtml), recording rainfall levels within the average for the region, on the contrary 2009 saw La Nina raising rainfall rates far above the average, followed in 2011 by moderate La Niña activity (CPTEC/INPE, 2009; Melo, 2011). The change in weather conditions caused modifications in the level and duration of flooding, resulting in marked water table fluctuations, and was probably underlying trends found in the sites. For example, the increase in richness and diversity of species in 2009 , mainly due to the increase in annual species of the Cyperaceae and Lentibulariaceae, whereas lower rainfall in 2007 was related, for example, to an increase in annual species of Polygalaceae. The 
years preceding the samplings 2006, 2008, and 2010 also saw differing rainfall patterns, with higher rates in 2008. Hobbs and Mooney (1995) found that, in the California annual serpentine grassland, the effects of rainfall patterns in species composition may act mainly in years prior to field assessment, thanks to the variation in the rate of seed production.

The highest rainfall in 2009 may also have caused the decrease in coverage of some species, especially those with clump architecture (tussock), facilitating the development of other slender and annual species that

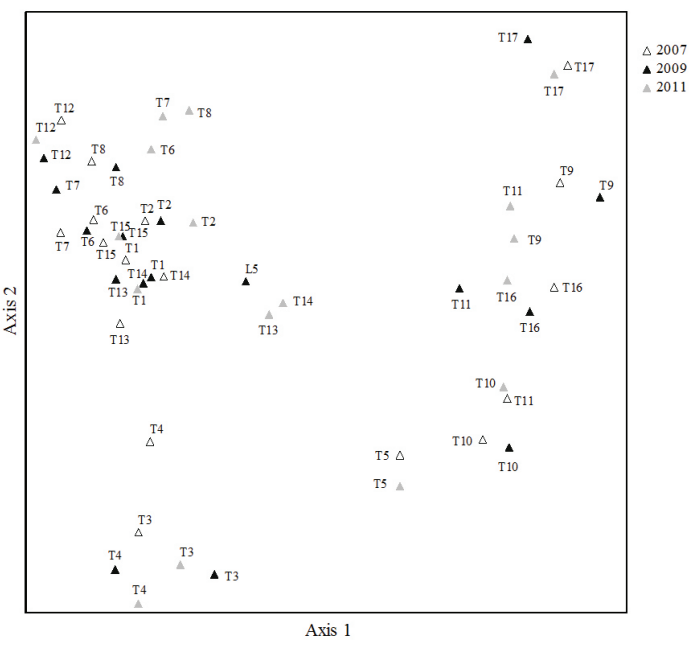

Figure 4. NMDS ordination diagram showing the separation into three groups in the ordination space of the 17 transects established in grassland areas of the Sete Cidades National Park, Piauí. Area 1 (T1 - T5), Area 2 (T6 - T8), Area 3 (T9 - T11), Area 4 (T12 - T13), Area 5 (T14 - T15), Area 6 (T16 - T17). remain suppressed, waiting for the opportunity to develop. The year 2007 saw the highest total of absolute coverage of perennial tussock species, as well as the lowest record of species for the total area, whereas in 2009 , the sum of these species accounted for $88.70 \%$ and $94.97 \%$ of the coverage for 2007 and 2011, respectively. Sampling wet grassland areas in Central Brazil, carried out in years with different precipitation rates, found an increase in richness and reduction of coverage by tussock species associated with increased precipitation (Eugênio et al., 2011).

The wet grasslands seem to exhibit a pattern of stability throughout the year, especially under conditions of major flooding and absence of human disturbances (Cianciaruso and Batalha, 2008; Munhoz and Felfili, 2008). Changes in community descriptors over longer intervals of time (interannual dynamics) were associated with suppression of disturbances, such as the absence of fire in the interval between samples of vegetation, and changes in rainfall patterns over time (Eugênio et al., 2011).

Studies in temperate grasslands that focus on smallscale dynamics have already shown high rates of species replacement (Herben et al., 2000). In the limestone grassland of Sweden the cumulative number of species in microsites of $0.01 \mathrm{~m}^{2}$ can double in a time interval of five years (Van Der Maarel and Sykes, 1993). In these fields, fluctuations in soil moisture and grazing pressures, as well in the characteristics of the life forms of species, occur over time, resulting in the appearance and disappearance of species, which is an important factor in the maintenance of stability of the communities. However, Klimeš (1999), did not confirm the high mobility of species expected for fields with high richness in ranges from 0.0025 to $2.25 \mathrm{~m}^{2}$ studied in the Czech Republic, and found an inverse pattern, where the probability of species occupying the same plot over seven years was high.

Table 3. Characteristics of the functional groups produced by cluster analysis for a set of 23 attributes and 92 species sampled in the Sete Cidades National Park, Piauí, Brazil.

\begin{tabular}{|c|c|c|c|}
\hline $\begin{array}{l}\text { Functional } \\
\text { groups }\end{array}$ & Short name & $\begin{array}{c}\text { Species } \\
\text { Number }\end{array}$ & Features \\
\hline FG1 & $\begin{array}{l}\text { non-tussock } \\
\text { hemicryptophytes I }\end{array}$ & 21 & $\begin{array}{l}\text { Perennial plants; NTH (includes the species Hv); Height categories } \\
\geq \mathrm{H} 3 \text { and } \leq \mathrm{H} 5 \text {; Flower traits varied; dispersion: mainly autochory. }\end{array}$ \\
\hline FG2 & $\begin{array}{l}\text { non-tussock } \\
\text { hemicryptophytes II }\end{array}$ & 6 & $\begin{array}{l}\text { Perennial plants; NTH (includes the species Ho); Height } \\
\text { categories } \geq \mathrm{H} 1 \text { and } \leq \mathrm{H} 3 \text { (except Elep hir); the flowers are in } \\
\text { classes P2 and P5; dispersion: mainly zoochory. }\end{array}$ \\
\hline FG3 & chamaephyte & 12 & $\begin{array}{l}\text { Perennial plants; Ch; Height categories } \geq \mathrm{H} 2 \text { and } \leq \mathrm{H} 5 \text {; Flower } \\
\text { traits varied; dispersion: mainly autochory. }\end{array}$ \\
\hline FG4 & $\begin{array}{l}\text { tussock } \\
\text { hemicryptophytes }\end{array}$ & 10 & $\begin{array}{l}\text { Perennial plants; } \mathrm{TH} \text {; Height categories } \geq \mathrm{H} 3 \text { and } \leq \mathrm{H} 5 \text {; Only } \\
\text { group P1 floral (wind pollination); dispersion: mainly autochory } \\
\text { and zoochory. }\end{array}$ \\
\hline FG5 & geophyte & 2 & $\begin{array}{l}\text { Perennial plants; G; only height categories H3; dispersion: } \\
\text { anemochory. }\end{array}$ \\
\hline FG6 & therophytes I & 24 & $\begin{array}{l}\text { Annual plants; Th; Height categories } \geq \mathrm{H} 1 \text { and } \leq \mathrm{H} 3 \text {; Flower } \\
\text { traits varied; dispersion: anemochory, autochory and zoochory. }\end{array}$ \\
\hline FG7 & therophytes II & 17 & $\begin{array}{l}\text { Annual plants; Th; Height categories } \geq \mathrm{H} 1 \text { and } \leq \mathrm{H} 5 \text {; Flower } \\
\text { traits varied; dispersion: autochory and zoochory. }\end{array}$ \\
\hline
\end{tabular}




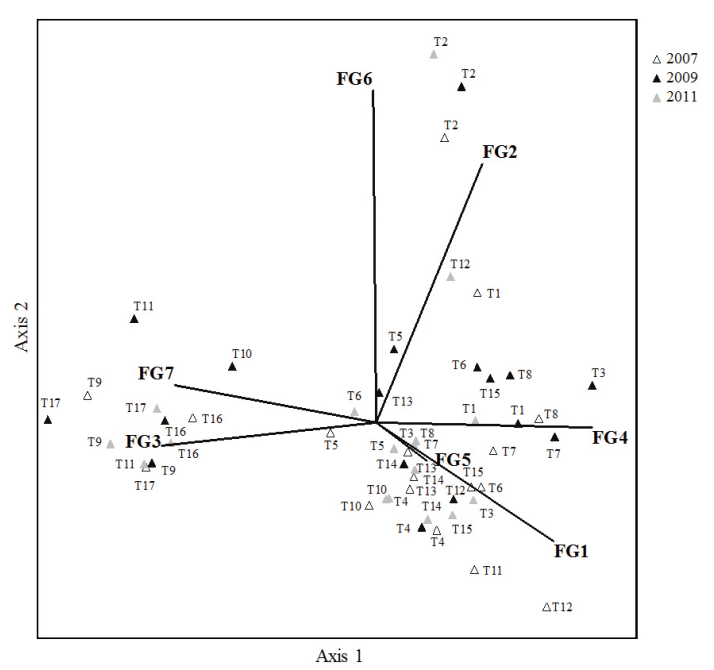

Figure 5. PCA ordination diagram of the functional groups and the 17 strain samplings of vegetation established in grassland areas of the Sete Cidades National Park, Piauí. Vectors indicate the relative association of functional group abundance with the two ordination axes, where their length represents the range of that association. Area 1 (T1 - T5), Area 2 (T6 - T8), Area 3 (T9 - T11), Area 4 (T12 - T13), Area 5 (T14 - T15), Area 6 (T16 - T17).

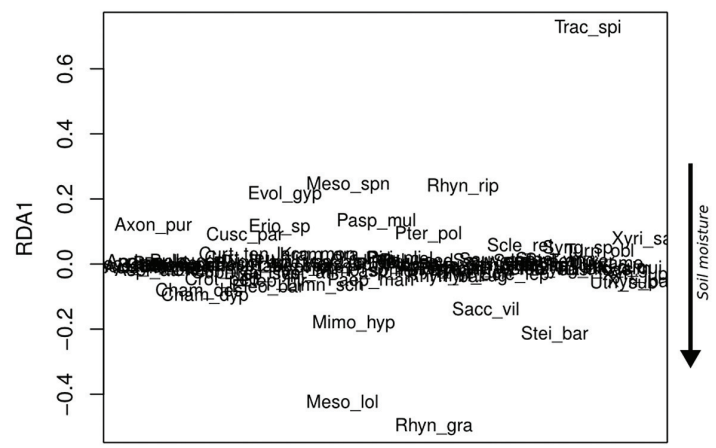

Figure 6. Autovalues produced in partial RDA of the plant cover explained by soil moisture minus the time effect. The arrow shows the direction of soil moisture gradient representation. The horizontal position of species names is random.

The fragments of moist grassland in ParnaSC separated by differences in soil moisture showed similar patterns in dynamics 2007, 2009, and 2011, with separation of the wetter areas (three and six) from the other (one, two, four and five) as seen in the NMDS, in which the similar transect ordination scores ordained close to each other by similar responses of species composition and structure. When the analysis was performed by considering the functional groups we observed a trend towards group cohesion over time, confirming the idea that structure and composition of the community is maintained by the existence of environmental filters that select the species through their environment occupation strategies (Keddy, 1992; Díaz et al., 1999; Cianciaruso and Batalha, 2008). In ParnaSC, chamaephytes and therophytes were associated with the wetter areas, while the drier areas were dominated mainly by tussock and non-tussock hemicriptophytes. According to Díaz et al. (1999) the ecological filters act on historical and biogeographic factors operating over large space and time scales.

Similar results in NMDS and PCA ordination show that functional classification was not independent of taxonomic affiliation. In all functional groups there were phylogenetically related species, yet the main functional groups of attributes were the life history of species and Raunkiaer's life-form class. According to Diaz and Cabido (1997) and Diaz et al. (1998) the ecological importance of groups should not be dismissed by their association with phylogeny. Except for the FG5, formed only by two Habenaria species (geophytes), the other six groups in ParnaSC grassland also comprised different botanical families, but with similar characteristics. In an analysis spanning three continents, Diaz et al. (2004) joined the families Asteraceae, Fabaceae and Poaceae in the same functional group as they did not differ significantly regarding the main environmental processes.

The separation of groups of species based on similar floral characteristics was not evident. The fragility of pollination syndromes has been shown in the literature mainly because animals vary in ability to discriminate the color of flowers, as well as in the possibility of more than one type of pollination for each plant species (Mayfield et al., 2001; Willmer, 2011). Moreover, in the cerrado the two largest classes of pollinators, bees and small insects, visit flowers of different colors (Martins and Batalha, 2006).

The results suggest that we found a non-accelerated dynamics, at least on a few-year scale, represented by some community descriptors, such as high similarity between the inventory and ordination of sample transects, mainly due to soil conditions in the areas like differences in moisture and fertility (Mendes et al., 2012). Analyses that took into account the spatial and temporal effects revealed a strong influence of the sampling lines on the space relationship. Therefore, besides considering the partition of the temporal niche as a mechanism for co-existence of species with similar functional characteristics (Rusch and Van Der Maarel, 1992), we must consider the heterogeneity of space, dictated by environmental filters that remain over time.

Acknowledgements - To Dr. Jeanine Maria Felfili (in memoriam) for her valuable help at the beginning of this work study. To CNPq-Programas PELD. To FAPEPI for the doctorate grant. To Jessica Viana Sousa and Larissa Vieira and Rosemary Vieira for their support in the fieldwork. To CAPES for the PNPD fellowship to F.S.C Takahashi. 


\section{References}

ANDERSON, MJ., 2001. A new method for nonparametric multivariate analysis of variance. Austral Ecology, vol. 26, no. 1, p. 32-46.

BAKKER, JP., OLFF, H., WILLEMS, JH. and ZOBEL, M., 1996. Why do we need permanent plots in the study of long-term vegetation dynamics? Journal of Vegetation Science, vol. 7, no. 2, p. 147-156. http://dx.doi.org/10.2307/3236314

BELLO, F., LEPŠ, J. and SEBASTIÀ, MT., 2006. Variations in species and functional plant diversity along climatic and grazing gradients. Ecography, vol. 29, no. 6, p. 801-810. http://dx.doi. org/10.1111/j.2006.0906-7590.04683.x

BOX, EO., 1996. Plant functional types and climate at the global scale. Journal of Vegetation Science, vol. 7, no. 3, p. 309-320. http://dx.doi.org/10.2307/3236274

CANFIELD, R., 1941. Application of line interception in sampling range vegetation. Journal of Forestry, vol. 39, no. 4, p. 388-394.

CHAO, A., CHAZDON, RL., COLWELL, RK. and SHEIN, TJ., 2005. A new statistical approach for assessing similarity of species composition with incidence and abundance data. Ecology Letters, vol. 8, no. 2, p. 148-159. http://dx.doi.org/10.1111/j.14610248.2004.00707.x

CIANCIARUSO, MV. and BATALHA, MA., 2008. A year in a Cerrado wet grassland: a non-seasonal island in a seasonal. Brazilian Journal of Biology, vol. 68, no. 3, p. 495-501. http:// dx.doi.org/10.1590/S1519-69842008000300005

COLWELL, RK., 2006. EstimateS 7.5 - Statistical estimation of species richness and shared species from samples. Storrs: University of Connecticut. 20 p. Software.

CPTEC/INPE, 2009. Estabelecida uma situação de transição entre o episódio La Niña e um possível El Niño. Infoclima: Boletim de informações climáticas, vol. 5, no. 1, p. 1-3.

DIAZ, S. and CABIDO, M., 1997. Plant functional types and ecosystem function in relation to global change. Journal of Vegetation Science, vol. 8, no. 4, p. 463-474. http://dx.doi. org/10.2307/3237198

DIAZ, S., CABIDO, M. and CASANOVES, F., 1998. Plant Functional Traits and Environmental Filters at a Regional Scale. Journal of Vegetation Science, vol. 9, no. 1, p. 113-122. http:// dx.doi.org/10.2307/3237229

DÍAZ, S., CABIDO, M., ZAK, M., MARTÍNEZ, CE. and ARANÍBAR, J., 1999. Plant functional traits, ecosystem structure and land-use history along a climatic gradient in central-western Argentina. Journal of Vegetation Science, vol. 10, no. 5, p .651-660.

DIAZ, S., HODGSON, JG., THOMPSON, K., CABIDO, M., CORNELISSEN, JHC., JALILI, A., MONTSERRAT-MARTÍ, G., GRIME, JP., ZARRINKAMAR, F., ASRI, Y., BAND, SR., BASCONCELO, S., CASTRO-DÍEZ, P., FUNES, G., HAMZEHEE, B., KHOSHNEVI, M., PÉREZ-HARGUINDEGUY, N., PÉREZ-RONTOMÉ, MC., SHIRVANY, FA., VENDRAMINI, F., YAZDANI, S., ABBAS-AZIMI, R., BOGAARD, A., BOUSTANI, S., CHARLES, M., DEHGHAN, M., TORRES-ESPUNY, L., FALCZUK, V., GUERRERO-CAMPO, J., HYND, A., JONES, G., KOWSARY, E., KAZEMI-SAEED, F., MAESTROMARTÍNEZ, M., ROMO-DÍEZ, A., SHAW, S., SIAVASH, B., VILLAR-SALVADOR, P. and ZAK, MR., 2004. The plant traits that drive ecosystems: Evidence from three continents. Journal of Vegetation Science, vol. 15, no. 3, p. 295-304. http://dx.doi. org/10.1111/j.1654-1103.2004.tb02266.x

DIECKMANN, U., HERBEN, T. and LAW, R., 1999. SpatioTemporal Processes in Ecological Communities. Quarterly, vol. 12, no. 3-4, p. 213-238.

DRAY, S., LEGENDRE, P. and PERES-NETO, PR., 2006. Spatial modelling: a comprehensive framework for principal coordinate analysis of neighbour matrices (PCNM). Ecological Modelling, vol. 196, p.483-493. http://dx.doi.org/10.1016/j. ecolmodel.2006.02.015

EUGÊNIO, COU., MUNHOZ, CBR. and FELFILI, JM., 2011. Dinâmica temporal do estrato herbáceo-arbustivo de uma área de campo limpo úmido em Alto Paraíso de Goiás, Brasil. Acta Botanica Brasilica, vol. 25, no. 4, p. 497-507.

GODINEZ-DOMINGUEZ, E. and FREIRE, J., 2003. Informationtheoretic approach for selection of spatial and temporal models of community organization. Marine Ecology-Progress Series, vol. 253, p. 17-24. http://dx.doi.org/10.3354/meps253017

GUIMARÃES, AJM., ARAÚJO, GM., OLIVEIRA, AA. and CORRÊA, GF., 2002. Estrutura fitossociológica de uma área natural e antropizada de uma vereda de Uberlândia, MG. Acta Botanica Brasilica, vol. 16, no. 3, p. 317-329.

GUREVITCH, J., SCHEINER, SM. and FOX, GA., 2009. Ecologia vegetal. 2. ed. Porto Alegre: Artmed. 592 p.

HAMMER, Ø., HARPER, DAT. and RYAN, PD., 2001. PAST: Paleontological Statistics software package for education and data analysis. Palaeontologia Electronica, vol. 4, no. 1, p. 1-99.

HERBEN, T., DURING, HJ. and LAW, R., 2000. Spatio-temporal Patterns in Grassland Communities. In DIECKMANN, U., LAW, R. and METZ, JAJ. (Eds.). The Geometry of Ecological Interactions: Simplifying Spatial Complexity. Cambridge: Cambridge University Press. p. 48-64.

HOBBS, RJ. and MOONEY, HA., 1995. Spatial and Temporal Variability in California Annual Grassland: Results from a LongTerm Study. Journal of Vegetation Science, vol. 6, no. 1, p. 43-56. http://dx.doi.org/10.2307/3236255

HUNTLEY, B., 1991. How plants respond to climate change: migration rates, individualism and the consequences for communities. Annals of Botany, vol. 67, no. 1, p. 15-22.

Instituto Brasileiro do Meio Ambiente e dos Recursos Naturais Renováveis - IBAMA, 2005. Plano operativo de prevenção e combate aos incêndios do Parque Nacional de Sete Cidades-PI, Piracuruca. Brasília: MMA.

KEDDY, PA., 1992. Assembly and response rules: two goals and predictive community ecology. Journal of Vegetation Science 3, no. 2, p. 157-164. http://dx.doi.org/10.2307/3235676

KLIMEŠ, L., 1999. Small-scale plant mobility in a species-rich grassland. Journal of Vegetation Science, vol. 10, no. 2, p. 209-218.

LAVOREL, S. and GARNIER, E., 2002. Predicting changes in community composition and ecosystem functioning from plant traits: revisiting the Holy Grail. Functional Ecology, vol. 16, p. 545-556. http://dx.doi.org/10.1046/j.1365-2435.2002.00664.x

LEGENDRE, P. and GALLAGHER, E., 2001. Ecologically meaningful transformations for ordination of species data. Oecologia, vol. 129, p. 271-280. http://dx.doi.org/10.1007/s004420100716

MARTINS, FQ. and BATALHA, MA., 2006. Pollination systems and floral traits in cerrado woody species of the upper Taquari 
region (Central Brazil). Brazilian Journal of Biology, vol. 66, no. 2 , p. 543-552.

MATESANZ, S., BROOKER, RW., VALLADARES, F. and KLOTZ, S., 2009. Temporal dynamics of marginal steppic vegetation over a 26-year period of substantial environmental change. Journal of Vegetation Science, vol. 20, no. 2, p. 299-310. http://dx.doi.org/10.1111/j.1654-1103.2009.05489.x

MAYFIELD, MM., WASER, N. and PRICE, M., 2001. Exploring the' most effective pollinator principle' with complex flowers: bumblebees and Ipomopsis aggregata. Annals of Botany, vol. 88, no. 4, p. 591-596. http://dx.doi.org/10.1006/anbo.2001.1500

MCCUNE B. and MEFFORD, MJ., 2011. PC-ORD. Multivariate Analysis of Ecological Data. Version 6.0. Gleneden Beach: MjM Software.

MELO, ABC., 2011. Fenômeno La Ninã enfraquece no pacífico equatorial. Infoclima: Boletim de informações climáticas, vol. 3, no. 1, p. 1-3.

MENDES, MRA., MUNHOZ, CBR., SILVA JÚNIOR, MC. and CASTRO, AAJC., 2012. Relação entre a vegetação e as propriedades do solo em áreas de campo limpo úmido no Parque Nacional de Sete Cidades, Piauí, Brasil. Rodriguésia, vol. 63, no. 4, p. 971-984. http://dx.doi.org/10.1590/S2175-78602012000400014

MUELLER-DOMBOIS, D. and ELLENBERG, H., 1974. Aims and methods of vegetation ecology. New York: John Willey \& Sons. $547 \mathrm{p}$.

MUNHOZ, CBR. and FELFILI, JM., 2008. Fitossociologia do estrato herbáceo-subarbustivo em campo limpo úmido no Brasil Central. Acta Botanica Brasilica, vol. 22, no. 4, p. 905-913. http:// dx.doi.org/10.1590/S0102-33062008000400002

OKSANEN, J., BLANCHET, FG., KINDT, R., LEGENDRE, P., MINCHIN, PR., O'HARA RB., SIMPSON, GL., SOLYMOS, P., STEVENS, MHH. and WAGNER, H., 2012. Vegan: Community Ecology Package.

OLIVEIRA, MEA., 2004. Mapeamento, florística e estrutura da transição campo-floresta na vegetação (cerrado) do Parque Nacional de Sete Cidades, nordeste do Brasil. São Paulo: Universidade Estadual de Campinas. 151 p. Tese de Doutorado em Biologia Vegetal.

OLIVEIRA, MEA., MARTINS, FR., CASTRO, AAJF. and SANTOS, JR., 2007. Classes de cobertura vegetal do Parque Nacional de Sete Cidades (transição campo-floresta) utilizando imagens TM/Landsat, NE do Brasil. In Anais do XIII Simpósio Brasileiro de Sensoriamento Remoto, 2007. Florianópolis: INPE. p. $1775-1783$.

PECK, JE., 2010. Multivariate analysis for community ecologists: step-by-step using PCORD. Gleneden Beach: MjM Software.
PERES-NETO, PR., LEGENDRE, P., DRAY, S. and BORCARD, D., 2006. Variation partitioning of species data matrices: estimation and comparison of fractions. Ecology, vol. 87, p. 2614-2625. http:// dx.doi.org/10.1890/0012-9658(2006)87[2614:VPOSDM]2.0.CO;2

PILLAR, VD. and SOSINSKI-JR, EE., 2003. An improved method for searching plant functional types by numerical analysis. Journal of Vegetation Science, vol. 14, no. 3, p. 323-332. http://dx.doi. org/10.1111/j.1654-1103.2003.tb02158.x

REES, M., CONDIT, R., CRAWLEY, M., PACALA, S. and TILMAN, D., 2001. Long-Term Studies of Vegetation Dynamics. Science, vol. 293, no. 5530, p. 650-655. http://dx.doi.org/10.1126/ science. 1062586

RUSCH, G. and VAN DER MAAREL, E., 1992. Species turnover and seedling recruitment in limestone grasslands. Oikos, vol. 63, no. 1, p. 139-146. http://dx.doi.org/10.2307/3545523

ŠAMONIL, AE. and VRŠKA, T., 2008. Long-term vegetation dynamics in the Sumava Mts. Natural spruce-fir-beech forests. Plant Ecology, vol. 196, no. 2, p. 197-214.

THORNTHWAITE, CW. and MATHER, JR., 1955. The water balance. Publications in Climatology, vol. 3, no. 1. Centerton: Drexel Institute of Technology. $104 \mathrm{p}$.

VAN DER MAAREL, E., 1996. Pattern and processes in the plant community: fifty years after A.S. Watt. Journal of Vegetation Science, vol. 7, no. 1, p. 19-28. http://dx.doi.org/10.2307/3236412

VAN DER MAAREL, E. and SYKES, MT., 1993. Small scale plant species turnover in a limestone grassland: the carousel model and some comments on the niche concept. Journal of Vegetation Science, vol. 4, no. 2, p. 179-188. http://dx.doi.org/10.2307/3236103

VAN DER PIJL, L., 1982. Principles of dispersal in higher plants. 3th ed. New York: Springer Verlag. 214 p. http://dx.doi. org/10.1007/978-3-642-87925-8

VIOLLE, C., NAVAS, M., VILE, D., KAZAKOU, E., FORTUNEL, C., HUMMEL, I. and GARNIER, E., 2007. Let the concept of trait be functional! Oikos, vol. 116, no. 5, p. 882-892. http:// dx.doi.org/10.1111/j.0030-1299.2007.15559.x

WATT, AS., 1960. Population changes in acidiphilous grassheath in Breckland, 1936-57. Journal of Ecology, vol. 48, no. 3, p. 605-629. http://dx.doi.org/10.2307/2257337

WEIHER, E. and KEDDY, PA., 1995. The assembly of experimental wetland plant communities. Oikos, vol. 73, no. 3, p. 325-335. http://dx.doi.org/10.2307/3545956

WILLMER, P., 2011. Pollination and Floral Ecology. Princenton: Princeton University Press. 778 p.

ZAR, JH., 1999. Biostatistical analysis. 4th ed. New Jersey: Prentice-Hall. 663 p. 